\author{
Anna Januchta-Szostak \\ Agata Karaśkiewicz \\ Politechnika Poznańska \\ Wydział Architektury \\ anna.januchta-szostak@put.poznan.pl
}

\title{
ZAGOSPODAROWANIE REKREACYJNE DOLINY WARTY W MIASTACH WIELKOPOLSKI
}

\begin{abstract}
Abstrakt: Celem badań autorek była analiza struktury funkcjonalno-przestrzennej i stanu zagospodarowania terenów nadwarciańskich w miastach Wielkopolski pod kątem ich przydatności do rekreacji. Szczególną uwagę zwrócono na badanie dostępności rzeki i lokalizacji infrastruktury rekreacyjnej w dolinie Warty. Spośród 11 badanych miast Wielkopolski tylko w czterech: Koninie, Śremie, Poznaniu i Sierakowie, powstały odcinki bulwarów nadrzecznych. W pasie nadwodnym analizowanych miast znajduje się niewiele obiektów o funkcji rekreacyjnej związanej z wykorzystaniem sąsiedztwa rzeki. Atutem zagospodarowania turystycznego doliny Warty jest natomiast aktywizacja szlaku wodnego Wielkiej Pętli Wielkopolski, dzięki rosnącej liczbie przystani i marin, które znajdują się we wszystkich badanych miastach.
\end{abstract}

Słowa kluczowe: Warta, nadrzeczne bulwary, promenady, przestrzeń publiczna, infrastruktura rekreacyjna.

\section{WSTĘP}

Rzeki i doliny rzeczne stanowią ważny element struktury funkcjonalno-przestrzennej miast i regionów (m.in. TOŁWIŃSKI 1948, PANCEWICZ 2004, BERNAT 2007, MUSZYŃSKA-JELESZYŃSKA 2013), a ich potencjał rekreacyjny, rozumiany jako „zdolność krajobrazu do wytworzenia warunków umożliwiających zaspokojenie potrzeb związanych z wypoczynkiem i odtwarzaniem sił biopsychofizycznych" (RICHLING 1992), jest podstawą zagospodarowania rekreacyjnego.

Potencjał rekreacyjny miejskich odcinków dolin rzecznych uwarunkowany jest nie tylko jakością środowiska naturalnego i walorami krajobrazu kulturowego, ale również dostępnością brzegów rzeki, ciągłością szlaków nadbrzeżnych i wodnych oraz ilościowym i jakościowym stanem infrastruktury rekreacyjnej.

Struktura zagospodarowania rekreacyjnego wiąże się z pojęciem Terytorialnego Systemu Rekreacyjnego (PRIEOBRAŻENSKIJ, WIEDIENIN 1971), obejmującym walory przyrodnicze i antropogeniczne, infrastrukturę techniczną, zatrudnionych $\mathrm{w}$ obsłudze ruchu turystycznego i organy nim zarządzające, a także uczestników wypoczynku (rekreantów) (PIETRZAK 2013). $\mathrm{W}$ prezentowanych badaniach autorki koncentrują się przede wszystkim na aspektach funkcjonalno-przestrzennych doliny Warty, a w szczególności roli zabudowy i zagospodarowania terenu oraz na elementach infrastruktury technicznej, determinującej możliwości pełnienia funkcji rekreacyjnej i turystycznej.

\section{CELE, ZAKRES I METODY BADAŃ}

Przedmiotem badań autorek są miejskie tereny nadrzeczne (MTN) i czynniki warunkujące ich zagospodarowanie ${ }^{1}$. Jedną $\mathrm{z}$ istotnych determinant jest zaspokajanie potrzeb rekreacyjnych mieszkańców miast oraz możliwości rozwoju turystyki w oparciu o potencjał krajobrazu i elementy infrastruktury rekreacyjnej dolin rzecznych. Wybrane elementy tych badań mogą być przydatne do aktualizacji stanu wiedzy $\mathrm{w}$ zakresie zagospodarowania rekreacyjnego doliny Warty w Wielkopolsce.

Celem niniejszego artykułu była analiza struktury funkcjonalno-przestrzennej i stanu zagospodarowania terenów nadwarciańskich w miastach Wielkopolski z uwzględnieniem ich przydatności do pełnienia funkcji rekreacyjnej. Do badań zakwalifikowano 11 miast położonych nad Wartą, na szlaku Wielkiej Pętli Wielkopolski, w granicach województwa wielkopolskiego 
i były to: Konin, Pyzdry, Śrem, Puszczykowo, Luboń, Poznan, Oborniki, Obrzycko, Wronki, Sieraków i Międzychód.

Badania obejmowały:

- analizę przeznaczenia terenów nadrzecznych do pełnienia funkcji rekreacyjnych, poziomu ich zainwestowania oraz ograniczeń związanych z zagrożeniem i ryzykiem powodziowym;

- analizę dostępności i ciągłości zagospodarowania brzegów rzeki, ze szczególnym uwzględnieniem lokalizacji bulwarów i promenad nadrzecznych;

- analizę infrastruktury rekreacyjnej, w szczególności związanej z turystyką wodną, na podstawie lokalizacji i wyposażenia marin i przystani.

W badaniach zastosowano metodę map nakładkowych ${ }^{2}$ oraz analiz kartograficznych i statystycznych z wykorzystaniem dokumentów planistycznych, map zagrożenia i ryzyka powodziowego, a także porównanie wyników kwerend terenowych oraz analizy internetowych baz danych, w tym zdjęć satelitarnych, ortofotomap oraz ogólnodostępnych portali PIB (https://www.bip.gpv.pl)3 umożliwiających wielokryterialną analizę $\mathrm{z}$ możliwością koordynacji międzybranżowej.

\section{ZAGOSPODAROWANIE REKREACY]NE MIEJSKICH TERENÓW NADRZECZNYCH}

Doliny rzeczne w miastach są zwornikami struktur przyrodniczych i kulturowych. Styk tych środowisk jest obszarem o potencjalnie wysokich walorach rekreacyjnych, ale również miejscem konfliktów i zagrożeń (np. powodziowych czy środowiskowych). Odpowiednie zagospodarowanie rekreacyjne umożliwia poprawę dostępności oraz atrakcyjności funkcjonalnej i wizualnej tych terenów, a także ochronę cennych ekosystemów z zachowaniem chłonności naturalnej i drożności korytarzy migracyjnych. Zagrożenia powodziowe i uwarunkowania hydrologiczne są jednak powodem ograniczeń zainwestowania na obszarach nadrzecznych.

Potencjał percepcyjno-behawioralny (PRZEWOŹNIAK 1991), wyrażający się w oddziaływaniu krajobrazu na zmysły człowieka i wpływający na jego zachowania oraz podejmowane formy aktywności, ma kluczowe znaczenie dla oceny przydatności dolin rzecznych do pełnienia funkcji rekreacyjnej ${ }^{4}$ i turystycznej. Szerokie przedpole rzeki pozwala na ekspozycję panoramy miasta, co jest istotne zarówno z punktu widzenia turystyki (percepcja miasta z perspektywy dróg wodnych i nadwodnych szlaków turystycznych), jak i potrzeb rekreacyjnych mieszkańców (komfort dalekiego widoku). Nie zawsze jednak fronty wodne miast mają wysokie walory wizualne, na co mogą wpływać zdegradowana zabudowa i zieleń, ograniczenie widoku przez wały przeciwpowodziowe, jak również niska jakość infrastruktury rekreacyjnej i hydrotechnicznej.

W ocenie struktury funkcjonalno-przestrzennej i zagospodarowania miejskich terenów nadrzecznych pod kątem przydatności turystyczno-rekreacyjnej istotne znaczenie mają elementy powierzchniowe (obszarowe), punktowe i liniowe (KOWALCZYK, DEREK 2010), czyli obszary nadwodne miast (ich funkcje i walory krajobrazowe frontów wodnych), punkty (węzłowe przestrzenie publiczne oraz rozmieszczenie obiektów i infrastruktury turystyczno-wypoczynkowej), a także powiązania liniowe (system dróg, szlaków turystycznych i ścieżek zapewniających ciągłość tras nadwodnych, komunikację z miastem oraz dostępność brzegów rzeki). Szczególnie istotne są obiekty związane $\mathrm{z}$ aktywnością wodną i nadwodną, takie jak: plaże, przystanie, mariny rzeczne, kluby wioślarskie i jachtowe ${ }^{5}$, ale ofertę rekreacyjną wzbogacają również obiekty sportowe i kulturalne, które nie są ściśle związane z wykorzystaniem dostępu do wody, m.in. boiska i hale widowiskowe, strzelnice, stadiony, centra rozrywki, amfiteatry, muzea.

\section{BADANIA ZAGOSPODAROWANIA MIEJSKICH TERENÓW NADWODNYCH W NADWARCIAŃSKICH MIASTACH WIELKOPOLSKI POD KĄTEM ICH PRZYDATNOŚCI W REKREACJI}

W badaniach struktury funkcjonalno-przestrzennej terenów nadwarciańskich w 11 miastach Wielkopolski wyodrębniono elementy obszarowe, liniowe oraz punktowe i przeanalizowano ich wykorzystanie do pełnienia funkcji rekreacyjnej i turystycznej. Przeprowadzono analizy w zakresie:

- przeznaczenia terenów nadrzecznych do pełnienia funkcji rekreacyjnych;

- dostępności i ciągłości zagospodarowania brzegów, a w szczególności występowania bulwarów i promenad nadrzecznych jako powiązań liniowych; a także

- punktowych elementów infrastruktury rekreacyjnej, w szczególności marin i przystani, jako obiektów związanych z rekreacją i turystyką wodną. 


\subsection{PRZEZNACZENIE TERENÓW NADRZECZNYCH DO PEŁNIENIA FUNKCJI REKREACYJNEJ (ELEMENTY OBSZAROWE)}

Analizę funkcjonalną terenów nadrzecznych przeprowadzono metodą map nakładkowych ${ }^{6}$, opierając się na lokalnych dokumentach planistycznych i strategicznych, w tym Studium uwarunkowań i kierunków zagospodarowania przestrzennego (SUiKZP)7 , w celu określenia procentowego udziału terenów sportu i rekreacji oraz zieleni urządzonej w strefie MTN nadwarciańskich miast Wielkopolski ${ }^{8}$. Za strefę MTN uznano pas terenów nadrzecznych (obejmujący również terasę ponadzalewową) o szerokości około 100 m lub wyznaczony przez najbliższą ulicę równoległą do nabrzeża.

Z badań wynika (rys. 1), że najwyższy wskaźnik procentowy przeznaczenia terenów do pełnienia funkcji sportowej i rekreacyjnej oraz zieleni urządzonej ${ }^{9}$ jest zauważalny w Sierakowie i wynosi $27 \%$. W pozostałych miastach wskaźnik ten waha się pomiędzy 5,3\% (Puszczykowo) a 12,9\% (Wronki). W Pyzdrach, Obornikach i Obrzycku zapisy SUiKZP nie definiują kierunków zagospodarowania MTN jako obszarów sportu i rekreacji lub zieleni urządzonej. W Koninie tereny przeznaczone do rekreacji stanowią niespełna $2 \%$, natomiast w Poznaniu zajmują około $17 \%$.

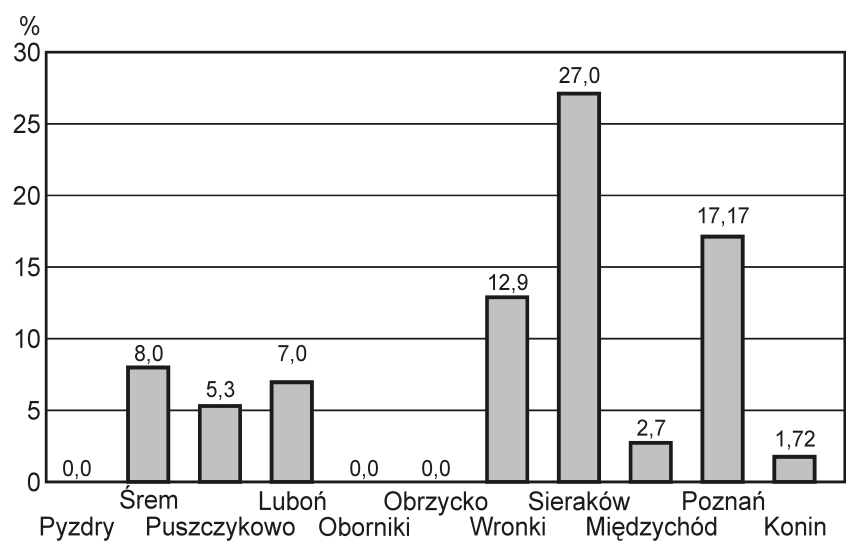

Rys. 1. Udział procentowy terenów przeznaczonych do pełnienia funkcji sportu i rekreacji oraz zieleni urządzonej w pasie MTN na podstawie obowiązującego SUiKZP

Źródło: oprac. A. Karaśkiewicz (z d. Florkowska)

W miastach nadwarciańskich Wielkopolski przeprowadzono również analizę funkcji rekreacyjnych na terenach zagrożonych powodzią. $\mathrm{Na}$ podstawie map zagrożenia i ryzyka powodziowego ${ }^{10}$ określono procentowy udział terenów rekreacyjnych na obszarach szczególnie narażonych na powódź11 i zalanie w przypadku przerwania wałów przeciwpowodziowych.

Ze wszystkich badanych miast Wielkopolski, znajdujących się na obszarach szczególnego zagrożenia powodzią, tereny rekreacyjne występują tylko we Wronkach, gdzie zajmują około 11\%, oraz w Poznaniu (udział obszarów pełniących funkcję rekreacyjną w ogólnej powierzchni terenów szczególnego zagrożenia powodzią nie przekracza $0,5 \%)$.

W sześciu z badanych miast nadwarciańskich (Koło, Pyzdry, Śrem, Międzychód, Konin i Poznań) występuje infrastruktura przeciwpowodziowa w postaci wałów, a w trzech miastach (w Śremie, Koninie i Poznaniu), stwierdzono, że przeznaczono tereny do pełnienia funkcji rekreacyjnej na obszarach odciętych obwałowaniami (ale wciąż narażonych na zalanie w przypadku ich uszkodzenia), których udział wahał się od 5\% w Koninie do ponad 50\% w Poznaniu. W Śremie funkcja rekreacyjna na terenach narażonych na zalanie w przypadku uszkodzenia wału przeciwpowodziowego występuje na $20 \%$ ich powierzchni (rys. 2).

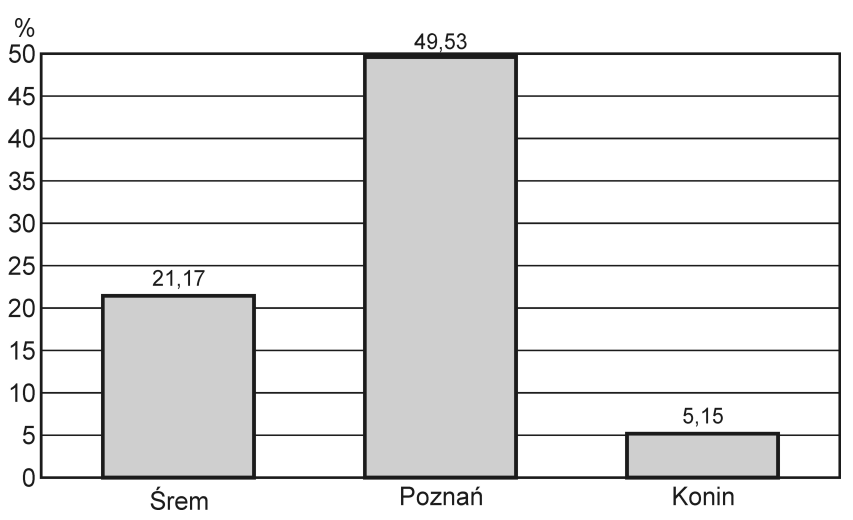

Rys. 2. Udział terenów rekreacyjnych na obszarach narażonych na zalanie w przypadku uszkodzenia wałów przeciwpowodziowych

Źródło: oprac. A. Karaśkiewicz (z d. Florkowska)

Wysoki wskaźnik procentowy przeznaczenia terenów do uprawiania rekreacji (27\%), odnotowany w małym mieście - Sierakowie, skłania do prowadzenia dalszych badań, w celu określenia czynników sprzyjających rozwojowi funkcji rekreacyjnych na terenach nadrzecznych. Być może w przypadku Sierakowa wynik ten jest efektem realizacji lokalnej strategii rozwoju nastawionej na wykorzystanie potencjału turystycznego miasta. Zróżnicowanie udziału procentowego przeznaczenia terenów do pełnienia funkcji rekreacyjnej w pasie MTN w poszczególnych miastach Wielkopolski może wynikać też z lokalnych uwarunkowań przestrzennych, zasięgu i poziomu zagrożenia powodziowego bądź czynników społeczno-ekonomicznych. Zastanawiający jest również niski wskaźnik funkcji rekreacyjnych w pasie MTP Konina (1,72\%) w kontekście realizacji długiego odcinka bulwarów w tym mieście.

Dokładne badania struktury funkcjonalnej MTN (JANUCHTA-SZOSTAK, FLORKOWSKA 2016, FLORKOWSKA 2017) w 11 miastach nadwarciańskich Wielkopolski potwierdziły najwyższy udział procentowy użytków 
zielonych oraz gruntów ornych, co jest odpowiednią formą zagospodarowania ze względów ekohydrologicznych. Dziwi jednak niewielki udział funkcji rekreacyjnych w kontekście powszechnie panującego przekonania o deficycie terenów rekreacyjnych w miastach.

Niewątpliwie wysoki poziom zainwestowania na terenach zagrożonych powodzią skutkuje wzrostem ryzyka powodziowego. Jest to jedna $z$ najważniejszych przyczyn ograniczania inwestycji (obok ograniczeń wynikających z Ustawy z 20 lipca 2017 r. - Prawo wodne) na obszarach szczególnego zagrożenia powodzią i na terenach narażonych na zalanie w przypadku przerwania wałów przeciwpowodziowych, jednak przeznaczenie terenów do pełnienia funkcji rekreacyjnej nie musi wiązać się z realizacją obiektów kubaturowych.

Do oceny przydatności rekreacyjnej MTN niezbędna jest również analiza walorów estetycznych krajobrazu frontów wodnych (w tym zbadanie wpływu wałów przeciwpowodziowych na percepcję miasta i rzeki) oraz chłonności rekreacyjnej (w tym chłonności naturalnej). Analiza taka przewidziana jest na kolejnym etapie badań.

\subsection{ANALIZA DOSTĘPNOŚCI I CIĄGLOŚCI ZAGOSPODAROWANIA BRZEGÓW - BULWARY I PROMENADY NADRZECZNE (ELEMENTY LINIOWE INFRASTRUKTURY TURYSTYCZNO-REKREACYJNEJ)}

Liniowe elementy infrastruktury komunikacyjnej umożliwiają rekreacyjne użytkownie terenów wzdłuż rzeki (np. spacery, bieganie, jazdę na rowerze) oraz prowadzenie nadbrzeżnych tras turystycznych o szczególnych walorach widokowych. Dla aktywizacji rekreacyjnej MTN kluczowe znaczenie ma forma i dostępność nabrzeży, drożność doliny i ciągłość szlaków nadwodnych. Wykorzystanie rekreacyjne dolin rzecznych na obszarach zurbanizowanych wymaga zapewnienia dostępu do nich zarówno od strony lądu, jak i od strony wody (rys. 3). Analizy tego zagadnienia dokonano, by sprawdzić, które miasta nadwarciańskie posiadają bulwary i promenady nadrzeczne i jaki jest poziom dostępności brzegów od strony miasta. Dostępność od strony rzeki omówiono w kolejnym rozdziale, opierając się na wynikach badań dotyczących lokalizacji portów i przystani na drodze wodnej Warty.

Badania dostępności i zagospodarowania nabrzeży przeprowadzone zostały na podstawie analizy internetowych baz danych, w tym zdjęć satelitarnych, ortofotomap i ogólnodostępnych portali BIP. Wyniki zweryfikowano i uzupełniono metodą obserwacji i inwentaryzacji podczas kwerend terenowych w miastach nadwarciańskich.

Dostępność rzeki od strony miasta zbadano poprzez analizę powiązań komunikacyjnych poziomych i pionowych. W powiązaniach poziomych uwzględniono przebieg ulic i traktów pieszych (utwardzonych i gruntowych), szlaków turystycznych oraz ścieżek pieszych, tras rowerowych i traktów pieszo-rowerowych, natomiast jako powiązania pionowe zinwentaryzowano lokalizację schodów, ramp i zjazdów, umożliwiających pokonanie różnic wysokości pomiędzy poziomem zabudowy a rzeką ${ }^{12}$. Zwrócono również uwagę na pochylnie dostosowane dla osób niepełnosprawnych. Określono też długość bulwarów w miastach i jej stosunek do długości rzeki w granicach administracyjnych miast.

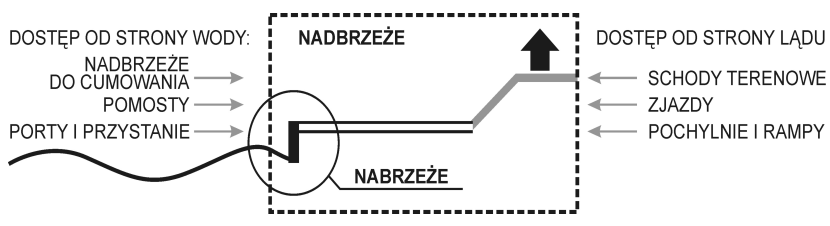

Rys. 3. Dostępność stref nabrzeża i nadbrzeża rzeki w miastach Źródło: oprac. A. Januchta-Szostak, A. Karaśkiewicz (z d. Florkowska)

Spośród wszystkich miast nadwarciańskich w Wielkopolsce $30 \%$ z nich posiada nadrzeczne trakty piesze w postaci bulwarów i promenad (rys. 4), są to: Konin, Śrem, Poznań i Sieraków.

W Śremie długość promenady wynosi około 2 km, co stanowi prawie 50\% długości rzeki w granicach administracyjnych miasta. Bulwary w Koninie (fot. 1) mają długość blisko $1 \mathrm{~km}$, co stanowi 9\% długości rzeki w granicach miasta. Łączna długość wybudowanych odcinków Wartostrady w Poznaniu (fot. 2) wynosi prawie $5 \mathrm{~km}$, czyli 23\% długości rzeki w mieście, natomiast promenada w Sierakowie (fot. 3), odługości około 200 m, ma bardzo symboliczny charakter i nie przekracza 3\% długości rzeki w mieście. W pozostałych miastach rolę ciągów komunikacji poziomej odgrywają odcinki ulic nadbrzeżnych (np. w Pyzdrach, Kole, Puszczykowie, Międzychodzie) oraz ścieżki gruntowe. Niekiedy nieformalne ścieżki nadwodne ${ }^{13}$ są bardzo trudno dostępne $\mathrm{z}$ uwagi na brak schodów czy zjazdów (np. w Obornikach). Dostęp do rzeki jest szczególnie utrudniony w przypadku miast wyżej położonych, jak np. Pyzdry (JANUCHTA-SZOSTAK, KARAŚKIEWICZ 2017). Stosunek długości bulwarów do długości rzeki w analizowanych miastach przedstawiono w tab. 1. na s. 20.

Na większości miejskich odcinków, pomimo regulacji rzeki i obwałowań, dolina Warty ma charakter półnaturalny o dużych walorach krajobrazowych, lecz słabej dostępności brzegów. Analiza potwierdziła niski stopień zagospodarowania MTN. Warto jednak podkreślić, że wszystkie odcinki bulwarów i promenad w miastach nadwarciańskich powstały w ciągu ostatnich ośmiu lat, co wyraźnie świadczy o wzroście zainteresowania terenami nadrzecznymi i stopniowej 


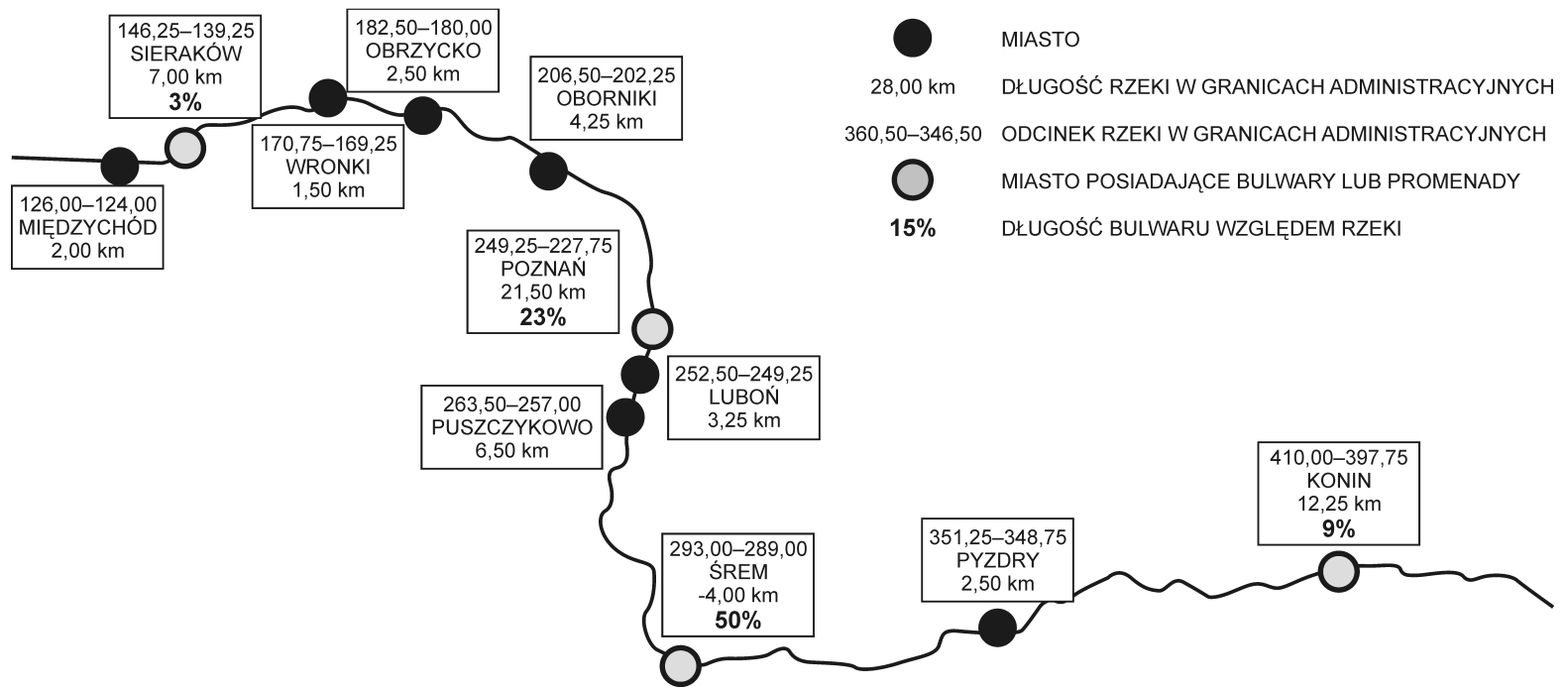

Rys. 4. Nadwarciańskie miasta Wielkopolski posiadające bulwary i promenady Źródło: oprac. A. Karaśkiewicz (z d. Florkowska)

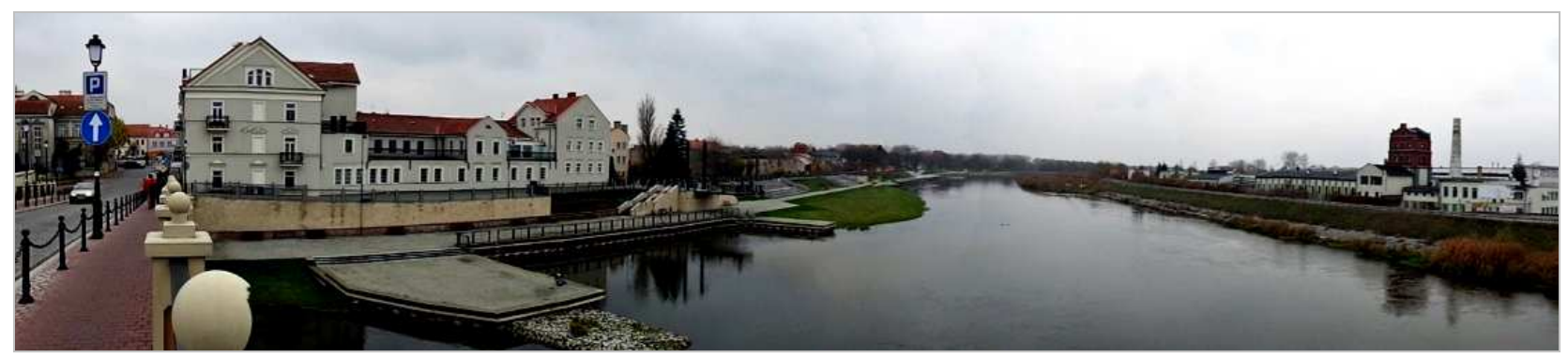

Fot. 1. Bulwar Nadwarciański w Koninie (fot. A. Januchta-Szostak)

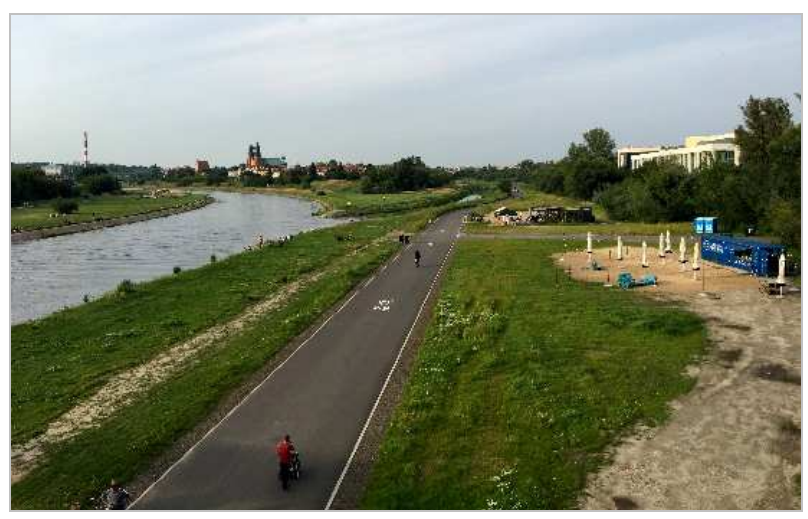

Fot. 2. Wartostrada w Poznaniu z sezonową infrastrukturą gastronomiczną - widok z mostu Rocha (fot. A. Karaśkiewicz z d. Florkowska)

aktywizacji rekreacyjnej. Poza naturalnością krajobrazu i bogactwem przyrody atutem nadwarciańskich miast Wielkopolski jest położenie historycznych rynków w niewielkiej odległości od rzeki ${ }^{14}$. To synergiczne powiązanie daje możliwość aktywizacji turystycznej obszarów nadrzecznych i promocji wizerunku miast. Atut ten jest jednak słabo wykorzystany w miastach

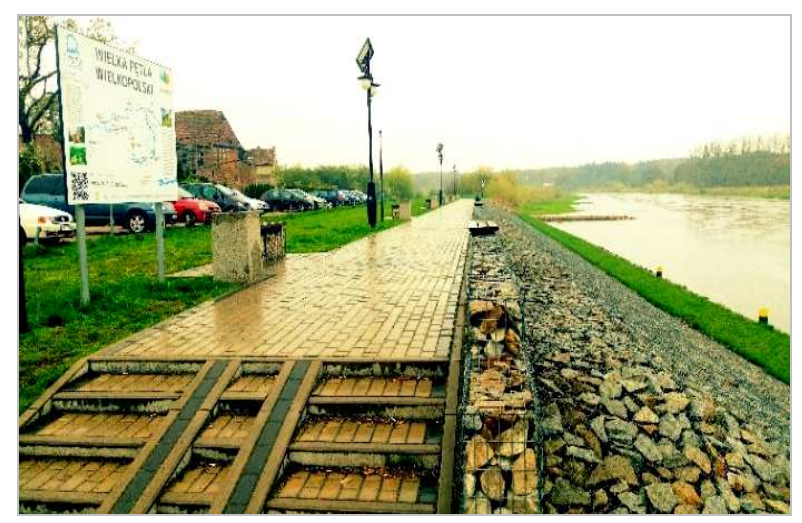

Fot. 3. Bulwar Nadwarciański w Sierakowie połączony z przystanią (fot. W. Henicz)

Wielkopolski z powodu niskiej jakości wizualnej frontów wodnych (badania dotyczące tego zagadnienia są w toku) i braku nadrzecznych bulwarów (np. w Obornikach czy Międzychodzie). Dobrym przykładem poprawy dostępności rzeki i połączenia nabrzeża z kompozycją miasta jest bulwar w Koninie, który sąsiaduje z placem Wolności i ortogonalnym układem kwartałów 
Tab. 1. Długość bulwarów w badanych miastach nadwarciańskich Wielkopolski w stosunku do długości rzeki w ich granicach administracyjnych

\begin{tabular}{|l|c|c|c|c|}
\hline Miasto & $\begin{array}{c}\text { Długość } \\
\text { bulwarów } \\
(\mathrm{km})\end{array}$ & $\begin{array}{c}\text { Długość rzeki w granicach } \\
\text { administracyjnych miasta } \\
(\mathrm{km})\end{array}$ & $\begin{array}{c}\text { Wskaźnik \% długości bulwarów } \\
\text { do długości rzeki w granicach } \\
\text { administracyjnych }\end{array}$ & $\begin{array}{c}\text { Rok powstania/otwarcia } \\
\text { bulwarów }\end{array}$ \\
\hline Konin & 1,0 & 12,5 & 9 & 2011 \\
\hline Śrem & 2,0 & 4,0 & 50 & 2009 \\
\hline Poznań & 5,0 & 21,5 & 23 & 2017 (nieoficjalne otwarcie) \\
\hline Sieraków & 0,2 & 7,0 & 3 & 2014 \\
\hline
\end{tabular}

Źródło: oprac. A. Karaśkiewicz (z d. Florkowska).

zabudowy, a główne ulice prostopadłe do rzeki zakończone są tarasami widokowymi.

Analizę dostępności i ciągłości zagospodarowania przeprowadzono tylko w miastach, jednak z punktu widzenia aktywizacji turystycznej MTN duże znaczenie ma drożność oraz ciągłość szlaków wodnych i nadbrzeżnych, a także infrastruktura turystyczna w skali całego regionu Wielkopolski ${ }^{15} \mathrm{i}$ drogi wodnej Warty.

\subsection{STAN ILOŚCIOWY I JAKOŚCIOWY INFRASTRUKTURY TURYSTYCZNO-REKREACYJNEJ (ELEMENTY PUNKTOWE)}

\section{Przystanie i mariny}

Dostępność miast nadwarciańskich z drogi wodnej Warty jest zdeterminowana lokalizacją przystani, marin, nabrzeży i pomostów do cumowania. Inwentaryzację i analizę tych obiektów $\mathrm{w}$ nadwarciańskich miastach Wielkopolski16 przeprowadzono poprzez badania kameralne źródeł bezpośrednich (także w zasobach internetowych $)^{17}$ oraz badania terenowe. Poglądową ocenę zagospodarowania i wyposażenia marin i przystani przeprowadzono, uwzględniając zestaw preferowanych elementów bazowych ${ }^{18}$, a następnie obliczono współczynnik ${ }^{19}$ zagospodarowania przystani, wynikający $\mathrm{z}$ dostępnych $\mathrm{w}$ danym miejscu elementów (zob. rys. 5 oraz por. tab. 2 na s. 21). Lokalizację i liczbę przystani względem kilometrażu rzeki Warty przedstawiono na rys. 6 (na s. 21).

Wszystkie analizowane miasta w Wielkopolsce posiadają przystanie, pozwalające dotrzeć do miasta od strony rzeki, choć jakość ich zagospodarowania i wyposażenia, wyrażona za pomocą poglądowego współczynnika zagospodarowania, wykazuje duże zróżnicowanie. Dość dobrze zagospodarowanymi przystaniami dysponują Konin, Pyzdry, Śrem, Poznań, Obrzycko (Zielonagóra) i Międzychód. W Obornikach z pięciu dostępnych przystani aktualnie czynne są tylko trzy, jednakże stopień ich zagospodarowania jest niski. Wszystkie czynne przystanie wyposażone są w podstawowe elementy umożliwiające cumowanie oraz zejście do wody, ale nie we wszystkich są toalety czy punkty gastronomiczne. W większości znajdują się ławki i miejsce na ognisko, brak jest jednak punktów pierwszej pomocy.

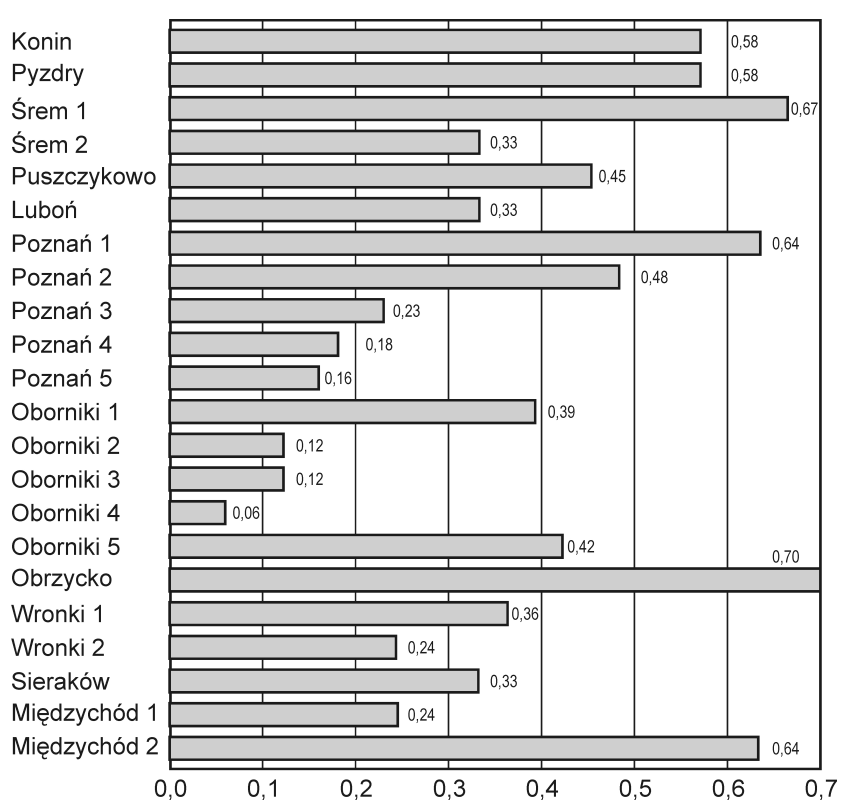

Rys. 5. Współczynnik zagospodarowania przystani i marin w wielkopolskich miastach nadwarciańskich

Źródło: oprac. A. Karaśkiewicz (z d. Florkowska)

\section{Baza rekreacyjno-sportowa}

Na podstawie źródeł internetowych i kwerendy terenowej w 11 miastach objętych badaniem przeprowadzono inwentaryzację obiektów pełniących funkcję rekreacyjną (w tym sportową i kulturalną), zlokalizowanych w pasie MTN. Celem tej części badań była analiza rozmieszczenia i zróżnicowania obiektów rekreacyjnych (budowli i obiektów otwartych) na terenach nadrzecznych oraz ich powiązań funkcjonalnych $\mathrm{z}$ doliną rzeki ${ }^{20}$.

Wyniki analizy wymagają jeszcze uzupełnienia i weryfikacji, jednak na podstawie wstępnego rozpoznania inwentaryzacyjnego można stwierdzić, że baza rekreacyjno-sportowa miast wielkopolskich $\mathrm{w}$ pasie 
Tab. 2. Wykaz przystani i marin w Wielkopolsce wraz z ich położeniem względem kilometra rzeki oraz obliczonym współczynnikiem zagospodarowania

\begin{tabular}{|c|c|c|c|c|}
\hline Miasto & Przystań/marina & $\begin{array}{l}\text { Odniesienie } \\
\text { do rys. } 5\end{array}$ & $\begin{array}{c}\text { Położenie względem } \\
\text { km rzeki }\end{array}$ & $\begin{array}{c}\text { Współczynnik } \\
\text { zagospodarowania }\end{array}$ \\
\hline Konin & Przystań przy Bulwarze & Konin & $403,5-404,5^{*}$ & 0,58 \\
\hline Pyzdry & Przystań Pyzdry & Pyzdry & 352,0 & 0,58 \\
\hline \multirow{2}{*}{ Śrem } & Przystań Miejska & Śrem 1 & 291,1 & 0,67 \\
\hline & Przystań Pasażerska & Śrem 2 & 291,8 & 0,33 \\
\hline Puszczykowo & Przystań wodna Puszczykowo-Niwka & Puszczykowo & 262,3 & 0,64 \\
\hline Luboń & Przystań Wioślarska & Luboń & 251,9 & 0,33 \\
\hline \multirow{5}{*}{ Poznań } & Przystań Posnania & Poznań 1 & 245,3 & 0,64 \\
\hline & KS Warta Przystań Kajakowa & Poznań 2 & 243,6 & 0,48 \\
\hline & Szeląg & Poznań 3 & 240,0 & 0,23 \\
\hline & Stary Port & Poznań 4 & 242,1 & 0,18 \\
\hline & Kontener Art & Poznań 5 & 243,1 & 0,16 \\
\hline \multirow{5}{*}{ Oborniki } & Przystań Kowale & Oborniki 1 & 205,7 & 0,39 \\
\hline & Przystań pomost w pizzerii „Zamkowa” & Oborniki 2 & 205,8 & 0,12 \\
\hline & Przystań ul. Wodna - nieczynna & Oborniki 3 & 205,0 & 0,12 \\
\hline & Stary Port - nieczynna & Oborniki 4 & 207,5 & 0,06 \\
\hline & Obornicka Marina & Oborniki 5 & 206,0 & 0,42 \\
\hline Obrzycko & $\begin{array}{l}\text { Przystań kajakowa z zapleczem sportowo- } \\
\text {-rekreacyjnym na terenie Zielonejgóry }\end{array}$ & Obrzycko & 182,3 & 0,70 \\
\hline \multirow{2}{*}{ Wronki } & Przystań Wronki na terenie Olszynek & Wronki 1 & 171,4 & 0,36 \\
\hline & Przystań „Na Skarpie” & Wronki 2 & 171,0 & 0,24 \\
\hline Sieraków & Przystań nad Wartą w Sierakowie & Sieraków & 145,0 & 0,33 \\
\hline \multirow{2}{*}{ Międzychód } & Stanica nad Wartą & Międzychód 1 & 127,5 & 0,24 \\
\hline & Stary Port & Międzychód 2 & 128,0 & 0,64 \\
\hline
\end{tabular}

* Położenie względem km rzeki określono na podstawie map zagrożenia powodziowego. W przypadku Konina ustalono położenie części bulwaru, ponieważ inwentaryzowane elementy występują na dłuższym odcinku rzeki. W pozostałych przypadkach podano ich punktowe położenie.

Źródło: oprac. A. Karaśkiewicz (z d. Florkowska).

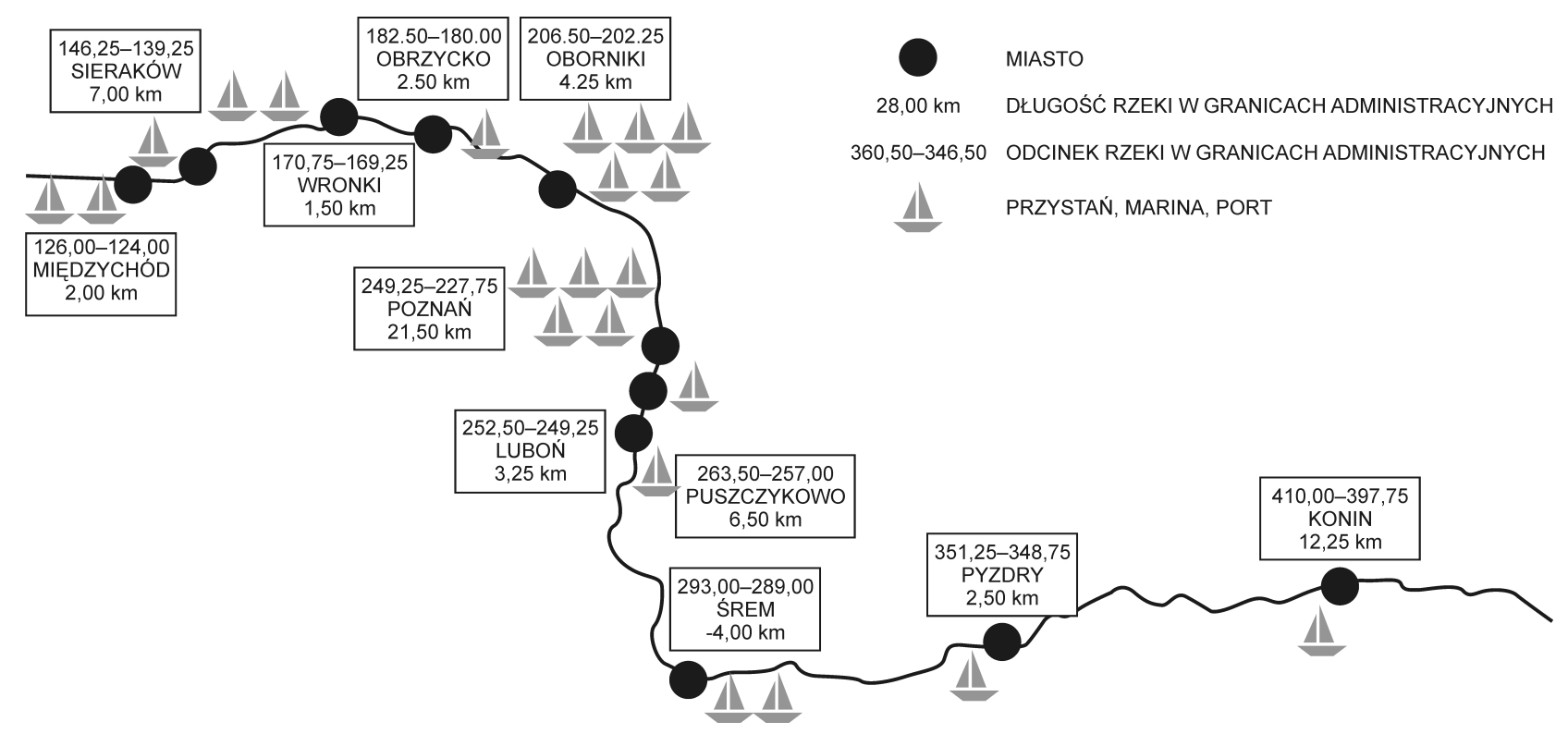

Rys. 6. Lokalizacja przystani i marin w Wielkopolsce

Źródło: oprac. A. Karaśkiewicz (z d. Florkowska) 
MTN jest dość skromna (najbogatszą ofertę obiektów rekreacyjnych ma Poznań). Wprawdzie zinwentaryzowano znaczną liczbę zróżnicowanych obiektów o funkcji rekreacyjno-sportowej, jednak zdecydowana większość z nich nie wykorzystuje bliskiego sąsiedztwa rzeki. Nierzadko jedynymi obiektami powiązanymi funkcjonalnie z doliną rzeki i wodą są przystanie rzeczne. Sporadycznie występują plaże miejskie (Poznań, Konin, Luboń) z wyposażeniem stałym lub sezonowym i miejsca piknikowe (np. drewniane altany nad Wartą w Puszczykowie). Niektóre obiekty gastronomiczne czy sportowe (boiska, hale sportowe) są powiązane $\mathrm{z}$ doliną rzeki jedynie widokowo, czyli korzystają z walorów nadwodnego krajobrazu, zwłaszcza że nadrzeczne panoramy wzbogacają dominanty krajobrazowe w postaci obiektów architektonicznych o dużym znaczeniu kulturowym (np. Zespół Klasztorny Franciszkanów w Pyzdrach czy zespół Starego Miasta i Ostrowa Tumskiego w Poznaniu). Niestety, jakość estetyczna niektórych obiektów rekreacyjnych (zwłaszcza tymczasowych, por. fot. 2) obniża walory krajobrazu doliny Warty ${ }^{21}$.
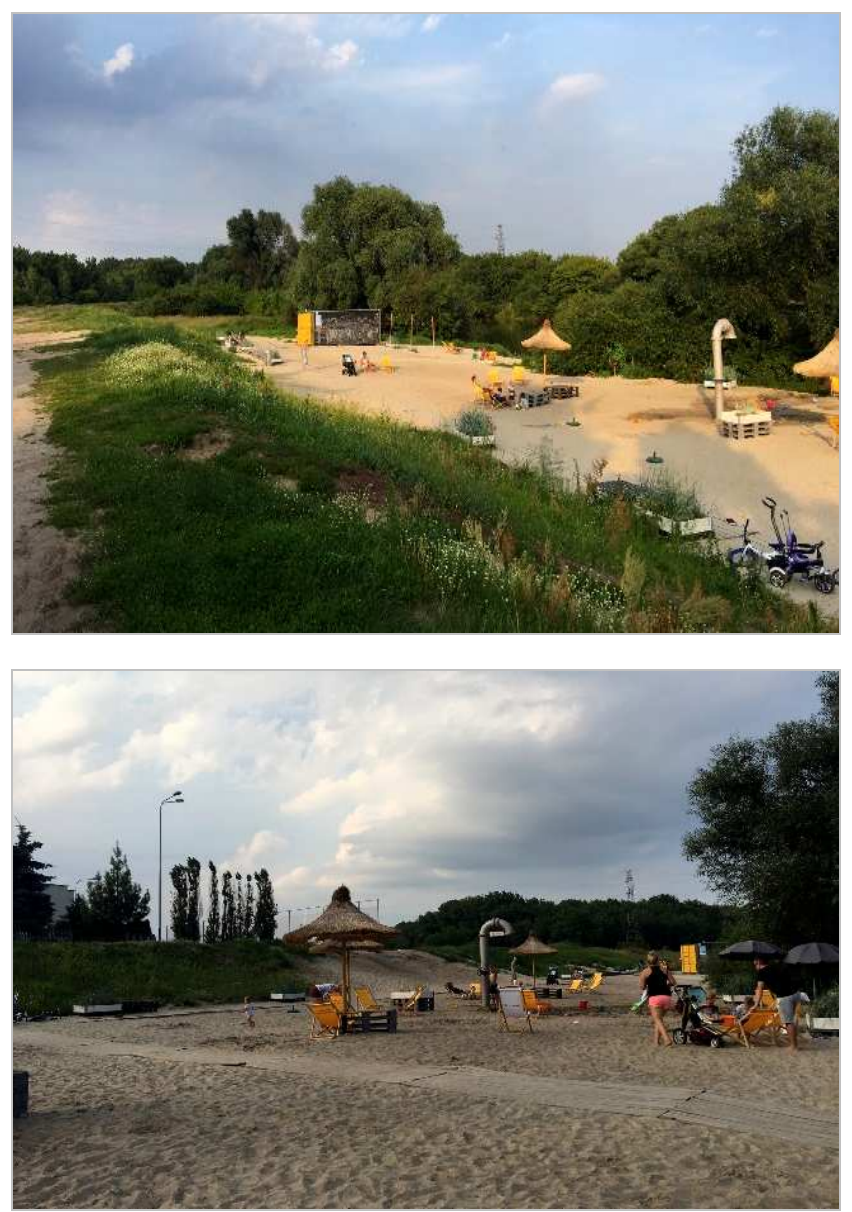

Fot. 4. Plaża miejska nad Wartą w Luboniu, lipiec 2017 (fot. A. Karaśkiewicz z d. Florkowska)

\section{PODSUMOWANIE I WNIOSKI}

Miasta nadwarciańskie Wielkopolski stopniowo zmieniają swój nadwodny wizerunek, co wiąże się również z aktywizacją miejskich terenów nadwodnych (MTN) i poprawą wykorzystania potencjału rekreacyjnego. Badania struktury funkcjonalno-przestrzennej i stanu zagospodarowania terenów nadwarciańskich w 11 miastach Wielkopolski umożliwiły zgromadzenie i wstępną analizę danych $\mathrm{w}$ zakresie przeznaczenia terenów nadrzecznych do pełnienia funkcji rekreacyjnej, dostępności i ciągłości zagospodarowania brzegów, a w szczególności występowania bulwarów i promenad nadrzecznych jako powiązań liniowych, a także lokalizacji i wyposażenia marin i przystani jako elementów punktowych infrastruktury rekreacyjnej, związanej z turystyką wodną.

Wskaźnik procentowy przeznaczenia terenów do uprawiania rekreacji w pasie MTN, ustalany na podstawie dokumentów planistycznych, jest niski i waha się w granicach od 0\% w Pyzdrach, Obornikach i Obrzycku do 27\% w Sierakowie, co wskazuje być może na niedobór urządzonych terenów rekreacji w większości objętych badaniem miast, a przynajmniej na brak uwzględnienia potencjału rekreacyjnego obszarów nadrzecznych w planowaniu przestrzennym. Na ograniczenia inwestycyjne w strefie MTN wpływa niewątpliwie poziom zagrożenia powodziowego, ale nie bez znaczenia są również kwestie własnościowe, legislacyjne i ekonomiczne, których oddziaływanie może być przedmiotem odrębnych badań.

Mimo to w ostatnich kilkunastu latach zauważalny jest wzrost inwestowania $\mathrm{w}$ infrastrukturę rekreacyjną miast nadwarciańskich, co wynika m.in. z wykorzystania środków unijnych. W Koninie, Śremie, Poznaniu i Sierakowie zbudowano odcinki bulwarów nadrzecznych. We wszystkich badanych miastach powstały przystanie (w niektórych nawet dwie lub trzy), co stanowi podstawę aktywizacji turystyki wodnej na szlaku Wielkiej Pętli Wielkopolski. Poziom zagospodarowania tych przystani jest jednak bardzo zróżnicowany.

W większości miast nadwodna infrastruktura rekreacyjna jest dość uboga i ogranicza się do przystani, sporadycznie pojawiają się plaże miejskie i miejsca piknikowe. Zwiększoną aktywność inwestycyjną w zakresie nadwodnej infrastruktury rekreacyjnej (zwłaszcza w postaci obiektów sezonowych) widać szczególnie w średnich i dużych miastach, których mieszkańcy coraz liczniej wykorzystują walory rzeki. 


\section{PRZYPISY}

1 W ramach projektu badawczego nr 10/01/DSPB/0260, finansowanego ze środków na działalność statutową MNiSW w roku 2016 i 2017 na Wydziale Architektury Politechniki Poznańskiej pt. „Proekologiczne kształtowanie miejsc publicznych budynków" (etap II).

2 Metoda map nakładkowych (overlay analisys) - metoda stosowana w kartografii, wykorzystywana także w architekturze krajobrazu i planowaniu przestrzennym (po raz pierwszy do tych celów zastosowana przez McHarga w latach 60. XX w. przy badaniach doliny rzeki Potomac) (MCHARG 1969). Rozwój metody map nakładkowych pozwolił na powstanie Systemu Informacji Geograficznej (GIS).

3 Biuletyn Informacji Publicznej - system stron internetowych, powstały w celu udostępniania informacji publicznej w postaci elektronicznej. Biuletyn ten składa się z witryn WWW, na których władze publiczne oraz inne podmioty wykonujące zadania publiczne udostępniają informacje publiczne wymagane przez polskie prawo (https://www.bip.gov.pl).

${ }^{4}$ Według badań M. PIETRZAKA (2013) rynny jeziorne i doliny rzeczne środkowej Wielkopolski uznane zostały za obszary o najwyższym potencjale percepcyjno-behawioralnym.

${ }^{5}$ Dla rozwoju turystyki kluczowe znaczenie ma również baza noclegowa i gastronomiczna, jednak w prezentowanych badaniach pominięto te komponenty.

${ }^{6} \mathrm{~W}$ badaniach wykorzystano załączniki graficzne SUiKZP miast nadwarciańskich $\mathrm{w}$ Wielkopolsce oraz zdjęcia satelitarne i podkłady geodezyjne definiujące badany obszar.

7 Ustawa z 27 marca 2003 r. o planowaniu i zagospodarowaniu przestrzennym.

8 Badania przeprowadzono w ramach zajęć „Pracownia badawcza - woda w architekturze i urbanistyce", prowadzonych na Wydziale Architektury Politechniki Poznańskiej w roku akademickim 2016/2017.

9 Rozróżnienie na funkcje sportu i rekreacji oraz zieleni urządzonej wynika z zapisów SUiKZP, ale wszystkie wymienione funkcje wiążą się z przeznaczeniem terenów do rekreacji.

10 Mapy zagrożenia powodziowego i mapy ryzyka powodziowego zostały opracowane w ramach projektu „Informatyczny System Osłony Kraju przed nadzwyczajnymi zagrożeniami" (ISOK) przez Instytut Meteorologii i Gospodarki Wodnej PIB - Centra Modelowania Powodzi i Suszy w Gdyni, Poznaniu, Krakowie i we Wrocławiu. Dostępne są w Hydroportalu KZGW, pod adresem: http://mapy.isok.gov.pl.

$11 \mathrm{~W}$ analizie uwzględniono obszary, na których prawdopodobieństwo wystąpienia powodzi jest średnie i wynosi raz na 100 lat (1\%).

12 Szerzej: A. JANUCHTA-SZOSTAK, A. KARAŚKIEWICZ (2017).

13 Przez nieformalne ścieżki nadwodne autorki rozumieją nieutwardzone piesze "przedepty", powstałe wskutek użytkowania przestrzeni rekreacyjnej, które nie są wskazane na mapach.

14 Zazwyczaj jest to odległość około $200 \mathrm{~m}$. Jedynie w Puszczykowie i Luboniu prawie $3 \mathrm{~km}$. W większości miast spacer z rynku nad rzekę trwa zaledwie $5 \mathrm{~min}$, a dojazd rowerem - 2 min. Szerzej: A. JANUCHTA-SZOSTAK, A. FLORKOWSKA (2016, s. $67-83)$.

15 Źródłem danych do dalszych badań zagospodarowania turystycznego może być „Dolina Warty” - studium rozwojowe dla województwa wielkopolskiego, opracowane przez Wojewódzkie Biuro Planowania Przestrzennego w Poznaniu, czy Strategia rozwoju turystyki w województwie wielkopolskim do 2020 roku, opracowana na zlecenie Urzędu Marszałkowskiego Województwa Wielkopolskiego.

16 Badania przeprowadzono w ramach zajęć „Pracownia badawcza - woda w architekturze i urbanistyce", prowadzonych na
Wydziale Architektury Politechniki Poznańskiej w roku akademickim 2016/2017.

17 Dostępność brzegów oraz lokalizacja infrastruktury wodnej na warciańskim odcinku Wielkiej Pętli Wielkopolski została opisana m.in. w przewodniku Wielka Pętla Wielkopolski autorstwa M. SŁOWIŃSKIEGO i G. NADOLNEGO (2007), a dane są aktualizowane na stronie http://www.wielka-petla.pl/wielka-petlawielkopolski.html.

18 Na potrzeby badań określono referencyjną bazę zagospodarowania i wyposażenia, obejmującą 33 elementy: pomosty, pomosty pływające, pomosty stałe, pomosty do cumowania, keje cumownicze, pale cumownicze, dalby, pławie, pochylnie do wodowania (slipy), przystanek tramwaju wodnego, nabrzeże umocnione wysokie, nabrzeże umocnione niskie, przyłącze wody, przyłącze elektryczne, odpompownia ścieków, oznakowanie na szlaku, zbiornik na śmieci, punkt pierwszej pomocy, wypożyczalnia sprzętu portowego, wypożyczalnia sprzętu wodnego, wyposażenie ratunkowe, basen postojowy, toaleta, bulwar, punkt gastronomiczny, ławki, stoły, altany, miejsce na ognisko, parking samochodów osobowych, dostęp/dojazd i zejście do wody.

${ }^{19}$ Współczynnik obliczono jako stosunek liczby zinwentaryzowanych elementów wchodzących w skład danej przystani do liczby elementów stanowiących bazę referencyjną, określoną przez autorki artykułu.

${ }^{20}$ Badano, które wymagają bezpośredniego dostępu do wody (np. są związane z różnymi formami rekreacji wodnej), a które wykorzystują jedynie walory krajobrazowe doliny.

21 Waloryzacja krajobrazu i badanie wpływu zagospodarowania rekreacyjnego na jakość wizualną frontów wodnych miast nadwarciańskich stanowi kolejny etap badań.

\section{BIBLIOGRAFIA}

BERNAT S., 2007, Rewitalizacja dolin rzecznych $w$ miastach, [w:] U. Myga-Piątek (red.), Doliny rzeczne. Przyroda - krajobraz - człowiek, Komisja Krajobrazu Kulturowego Polskiego Towarzystwa Geograficznego, s. 255-264.

FLORKOWSKA A., 2017, Funkcja na obszarach szczególnego zagrożenia powodziowego w nadwarciańskich miastach Wielkopolski, [w:] J. Nyćkowiak, J. Leśny (red.) Badania i rozwój młodych naukowców w Polsce. Architektura, Wyd. Młodzi Naukowcy, Poznań, s. 13-19.

JANUCHTA-SZOSTAK A., FLORKOWSKA A., 2016, Zagospodarowanie terenów nadrzecznych w nadwarciańskich miastach Wielkopolski, [w:] A. Januchta-Szostak, M. Banach (red.), Zrównoważone miasto - idee i realia, t. 1, ser. „Człowiek - Ekologia - Architektura", Wyd. Politechniki Poznańskiej, Poznań, s. 67-83.

JANUCHTA-SZOSTAK A., KARAŚKIEWICZ A., 2017, Nadrzeczne bulwary jako narzędzie regeneracji miejskiej przestrzeni publicznej - studium polskich miast, [w:] A. Januchta-Szostak, M. Banach (red.), Regeneracja miasta, t. 3, ser. „Człowiek - Ekologia - Architektura”, Wyd. Politechniki Poznańskiej, Poznań, s. 61-74.

KOWALCZYK A., DEREK M., 2010, Zagospodarowanie turystyczne, Wyd. Naukowe PWN, Warszawa, s. 34-57.

McHARG J., 1969, Design with nature, Doubleday/Natural History Press, New York, NY.

MUSZYŃSKA-JELESZYŃSKA D., 2013, Tereny nadrzeczne w aspekcie rozwoju i rewitalizacji miast, "Journal of Health Sciences", 3, 14, s. 99-107.

PANCEWICZ A., 2004, Rzeka w krajobrazie miasta, Wyd. Politechniki Śląskiej, Gliwice.

PIETRZAK M., 2013, Potencjat rekreacyjny - istota, treść i zakres pojęcia, „Problemy Ekologii Krajobrazu”: Rekreacja w krajobrazach o wysokim potencjale, XXXIV, s. 205-211. 
PRIEOBRAŻENSKIJ W.S., WIEDIENIN J.A., 1971, Geografia i oddych, Izd. Znanie, Moskwa.

PRZEWOŹNIAK M., 1991, Krajobrazowy system interakcyjny strefy nadmorskiej w Polsce, Uniwersytet Gdański, Gdańsk.

RicHLING A., 1992, Kompleksowa geografia fizyczna, PWN, Warszawa.

SŁOWIŃSKI M., NADOLNY G., 2007, Wielka Pętla Wielkopolski. Warta - Noteć - Gopto - Warta. Przewodnik nie tylko dla wodniaków, Satchwell, Warszawa.

TOŁWIŃSKI T., 1948, Urbanistyka, t. 1 i 2, Wyd. Ministerstwa Odbudowy, Warszawa.
Strategia rozwoju turystyki w województwie wielkopolskim do 2020 roku, 2015, Urząd Marszałkowski Województwa Wielkopolskiego, Poznań.

Ustawa z 27 marca 2003 r. o planowaniu i zagospodarowaniu przestrzennym.

Ustawa z 20 lipca 2017 r. - Prawo wodne.

http://mapy.isok.gov.pl/imap/; 02.04.2017.

http://www.wielka-petla.pl/wielka-petla-wielkopolski.html; 11.10.2017.

https://www.bip.gov.pl/; 24.02.2018.

Artykuł wpłyną:

11 stycznia $2018 \mathrm{r}$. Zaakceptowano do druku:

23 marca $2018 \mathrm{r}$ 